\title{
Hypophyseal Function in SHR
}

\section{Lysine Incorporation and ACTH Content}

\author{
Yukio YAmori,* Kiyoe OHTA, ${ }^{*}$ Ryoichi Horie, ${ }^{* *}$ and \\ Masayasu SATO***
}

Early morphological studies indicated that hypophyseal function in SHR was more active than that in normotensive controls (Okamoto, $\mathrm{K}$ ed: Spontaneous Hypertension, Springer-Igaku Shoin, New York, Berlin, Tokyo, 1972). Hypophyseal weight in SHR was proved to be increased, and this weight was closely correlated with blood pressure level in $\mathbf{F}_{2}$ offspring obtained by SHR and normotensive Wistar rats (Yamori, Ooshima, and Okamoto: Jap Circulat $\mathrm{J} 36$ : 561, 1972). Moreover, recent studies on the hypophyseo-thyroidal axis in SHR indicated that TSH in the pituitary and blood was markcdly increased with some reduction of $T_{3}, T_{4}$ Icvel in the plasma, and that these increased TSH levels wcre not affected by increased plasma level of exogenous thyroid hormones (Kojima, Takahashi, Ohno, Sato, Yamada, Kubota, Yamori, and Okamoto: Proc Soc Exp Biol Med, 1975). In the present study we studied the ${ }^{3} \mathrm{H}$-lysine incorporation into the pituitary in SHR with or without hypertension to analyze the function, and we measured ACTH content by a radioimmunoassay technique to examine the function of the hypophyseo-adrenal axis.

\section{Materials and Methods:}

(1) Thirty SHR in the prehypertensive stage (at the age of 40 days) were divided into 3 groups: apresoline-treated rats $(80 \mathrm{mg} / \mathrm{L}$ in the drink water), splanchnicotomized rats (splanchnicotomy plus mesenteric artery denervation), and nontreated rats. Eight Wistar-Kyoto (WK) rats were used as the normotensive controls in this study. On the 14th day of the experiment rats were sacrificed by decapitation 2 hours after ${ }^{3} \mathrm{H}$-lysine injection $(0.4 \mu \mathrm{C}$ / $\mathrm{Gm}$, i.v.). Pituitaries were homogenized and dialyzed to determine the radioactivity per $\mathrm{mg}$ protein of the dialysate by a scintillation counter. Or pituitaries solved in NCS solution $\left(\mathrm{P}_{2}\right)$ were counted for the radioactivity with the blood samples $\left(\mathrm{B}_{2}\right)$ collected at the sacrifice. Net pituitary incorporation $(\mathrm{P})$ was calculated by correcting the counts by the radioactivity of pituitaries $(\mathrm{Po})$ and blood (Bo) in the control group of rats, sacrificed immediately after ${ }^{3} \mathrm{H}$-lysine injection as follows: $\mathrm{P}=\mathrm{P}_{2}-\mathrm{B}_{2} \times \mathrm{Po} / \mathrm{Bo},(2)$ Four and 6-month-old

From the Departments of Pathology, ${ }^{*}$ Neurosurgery, ${ }^{* *}$ and Psychiatry, *** Faculty of Medicine, Kyoto University, Kyoto. 
each group, stroke-prone SHR (SHRSP), stroke-resistant SHR (SHRSP), and WK, 5 in each group, were sacrificed without any pretreatment, or with dexamethasone ( $1 \mathrm{mg} / \mathrm{Kg}$, i.p.) and nembutal (40 mg/Kg, i.p.) pretreatment, 2.5 and 1 hour prior to decapitation. Anterior lobes were immediately extirpated, weighed and homogenized in $1 \mathrm{ml}$ of $0.05 \mathrm{~N} \mathrm{HCl}$, and the supernatant was kept frozen at $-70^{\circ} \mathrm{C}$ until the radioimmunoassay of ACTH (Matsukura, West, Ichikawa, Jubiz, Harada, and Tyler: J Lab Clin Med 77: 490, 1971).

Results:

(1) Pituitary weights in SHRSP and SHRSR were significantly increased even at the age of 8 weeks in comparison with those in the age-matched WK. The weights of anterior lobes were also significantly increased in 4-month-old SHRSP and SHRSR. (2) ${ }^{3} \mathrm{H}$-lysine incorporation into the pituitary was significantly increased in SHR at the age of 8 weeks, compared with that in WK. This increase was still marked in SHR without hypertension, that is, splanchnicotomized SHR and apresoline-treated SHR. However, the radioactivity per $\mathrm{mg}$ protein of the pituitary was not significantly increased in SHR. (3) ACTH content per pituitary was significantly increased in SHRSP compared with WK, but this increase was not noted when ACTH content per $\mathrm{mg}$ wet weight was compared. After dexamethasone pretreatment, ACTH contents per pituitary as well as per mg wet weight were decreased in SHRSP and SHRSR, but such a decrease was not noted in WK.

${ }^{3} \mathrm{H}-\mathrm{Ly}$ sine Incorporation into Pituitary in SHR

\begin{tabular}{|c|c|c|c|c|}
\hline \multirow{2}{*}{$\begin{array}{l}\text { Experimental Groups } \\
\text { (No. of rats) }\end{array}$} & \multicolumn{3}{|c|}{ SHR } & \multirow{2}{*}{$\begin{array}{l}\text { Wistar-Kyoto } \\
\begin{array}{l}\text { Non-treated } \\
(8)\end{array}\end{array}$} \\
\hline & $\begin{array}{l}\text { Nontreated } \\
(10)\end{array}$ & $\begin{array}{l}\text { Apresoline- } \\
\text { treated }^{+}(10)\end{array}$ & $\begin{array}{l}\text { Splanch- } \\
\text { nicotomy (10) }\end{array}$ & \\
\hline Blood pressure & $168 \pm 2$ & $136 \pm 3^{* * *}$ & $136 \pm 3 * * *$ & $131 \pm 2 * * *$ \\
\hline Pituitary weight & $7.3 \pm 0.4$ & $7.6 \pm 0.2$ & $7.3 \pm 0.3$ & $5.9 \pm 0.3 * *$ \\
\hline $\begin{array}{l}\text { Net }{ }^{3} \mathrm{H} \text {-lysine incorporation } \\
\text { (dpm/pituitary) }\end{array}$ & $1,555 \pm 58$ & $1,869 \pm 55$ & $1,853 \pm 110$ & $1,164 \pm 76^{* * *}$ \\
\hline \multicolumn{5}{|c|}{$\begin{array}{l}\text { Mean } \pm \text { S.E. } *, * *, * * * \text { Significant differences from nontreated } \mathrm{SHR}(\mathrm{p}<0.05,0.01,0.001) \\
+: \text { Apresoline treatment }(80 \mathrm{mg} / \mathrm{L} \text { in drinking water) } \\
++: \text { Rats were sacrificed by decapitation } 2 \text { hours after }{ }^{3} \mathrm{H}-\mathrm{I} y \operatorname{sine}(0.4 \mu \mathrm{C} / \mathrm{Gm}, \mathrm{i} . \mathrm{v} .) \text { injection. Net } \\
\text { ituitary counts were corrected by subtracting blood counts. }\end{array}$} \\
\hline
\end{tabular}

Summary with Discussion:

Pituitary weights were already increased in SHR at the young stage (8 weeks of age) compared with WK. The weights of anterior lobes were also increased at the age of 4 months. This increase in weight appeared to have 
a functional significance as proved by the increased ${ }^{3} \mathrm{H}$-lysine incorporation into the pituitary. As the prevention of the development of hypertension by apresoline treatment or by splanchnicotomy had no effect on the increased lysine-incorporation, the acceleration of such a metabolism did not seem to be the secondary phenomenon to hypertension, but was supposed to be a primary alteration in SHR. ACTH content in the pituitary was increased in pretreatment of dexamethasone, ACTH content was rather decreased in SHR. 4-month-old SHRSP compared with the age-matched WK. After the acute pretreatment of dexamethasone, ACTH content was rather decreased in SHR. This finding suggested one possibility that dexamethasone did not efficiently block ACTH secretion from the pituitary in SHR.

(We appreciate Drs. S. Matsukura and Y. Hirata, Department of Internal Medicine, Kobe University School of Medicine, for their donation of ACTH antiserum and invaluable advice. This study was supported by the Science and Technology Agency of the Japanese Government, Ministry of Education, National Institutes of Health, U.S.A. (Grant HL 17754), Japan Society for the Promotion of Science, Japan Heart Foundation, and Japan Tabacco \& Salt Public Corporation.) 